\title{
Features of the Elementary School Teacher Training In the System of Higher Education in Russia at the Present Stage
}

\author{
Rezeda R. Khairutdinova ${ }^{1}$ \\ ${ }^{1}$ Kazan (Volga region) Federal University, Kazan, Russia \\ Correspondence: Rezeda R. Khairutdinova, Kazan (Volga region) Federal University, Kremlyovskaya Street 18, \\ Kazan, 420008, Russia.
}

Received: December 29, 2014

Accepted: January 22, 2015 Online Published: February 11, 2015

doi:10.5539/res.v7n4p77

URL: http://dx.doi.org/10.5539/res.v7n4p77

\begin{abstract}
Relevance of the studied problem is that in the system of pedagogical manpower training in Russian high school objective tendencies of modern education are still insufficiently considered. At the same time today requirements to the level of teachers training capable to initiate searching of effective models of the organization and the management of educational cognitive activity pupils at school acquire special importance. In the article on the basis of the comparative analysis and the assessment of modern pedagogical processes and the phenomena in Russia and abroad features of the elementary school teacher professional training in high school are identified. According to problems and nature of the research structural and comparative methods of the analysis are used. The experience described in article can be used to improve the system of professional teachers training.
\end{abstract}

Keywords: professional training of the elementary school teacher, modernization of the higher pedagogical education, improvement of pedagogical manpower training, innovative technologies, new forms of the organization of educational process

\section{Introduction}

Transition to new federal state educational standards put before Russian higher school a problem of the new organization of educational process, including the training of pedagogical manpower. The requirements to the level of teachers training capable to initiate searching of effective models of the organization and the management of educational cognitive activity pupils at school acquired special importance. (Nikolaev, 2011).

Meanwhile in the system of pedagogical manpower training objective tendencies of modern education are still insufficiently considered. The reason of such situation is lack of relations between the new purposes of teacher training, its new structure and old forms and methods of work with students. Other technologies of high school teachers training, which demand new ideas, innovations, researches, are necessary.

In the context of modernization of the higher pedagogical education studying and accounting the positive experience of the professional teacher training abroad have big perspective.

The analysis of educational policy of foreign countries showed that recently one of the main tendencies of the educational development in the world is increase of its quality on the basis of personal development that imposes new requirements to teachers training (Mayburov, 2003).

The current tendency of development of foreign school which are characterized by exactly designated conversion in the relations between the teacher and the pupil from subject—object to subject—subject relations, dialogue relations assuming the fullest self-realization of the potential by each pupil leads to modernization of teachers training process, to revision of organizational forms and methods of future teachers training. Pedagogical education of foreign countries today is directed to master by teachers the new methods and types of work which gives more freedom in a choice, allowing to facilitate the organization of educational process, to achieve a training individualization (Bogomolova, 2006).

Actual problem of teachers training in the leading countries of the world is the level and nature of scientific knowledge in subjects which they will teach at school. Many countries thus aim the considered balance of two main components of pedagogical education-knowledge of a subject and psychology and pedagogical training. In all countries considerable work on modernization of the content of education is carried out; the new programs, manuals, which are based on an interdisciplinary foundation, focusing on fundamental knowledge of 
humanitarian and natural sciences, are entered; new standards for teachers training are developed (Voskresenskaya, 2004).

In Great Britain in training of the modern teacher as professional the attention to pedagogical techniques, mastering of concrete skills of leading of educational work which are processed as in the course of traditional occupations - at seminars, practical works, laboratory works, and by application of new forms and methods of work with students intensified (Greaves, 1994).

Future teachers in Great Britain are more and more focused on respect for the pupil, on creating conditions for their self-realization and success in school life. The famous English teacher J. Whyte specifies that the teacher first of all has to consider the interest of the pupil - the person and the citizen (Jandhyala, 2005).

Special attention in teacher training in France for mass schools is paid on questions of school adaptation, integration and children training of various ethnic groups. Appropriate sections are included into pedagogical courses according to the recommendation of the educational European Union which task includes development of cooperation of the European countries for the purpose of harmonization of education systems (Cedelle, 2002).

In Germany teachers prepare development of pupils main competences: activity focused, subject (possession of cultural norms, foreign languages, technical and economic basic knowledge, etc.), methodical (independent thinking, ability to use information creatively, etc.) and social (communicative abilities, responsibility understanding, etc.) (Hohlmeier, 1999).

By training the teacher at the West German universities the training process individualization is carried out, contacts between teachers and students increase. The computerization becomes a basic element of all forms of education. The greatest place in the organization of educational process is given to seminars, trainings, free group discussions, the design activity which stimulate independence and initiative of students in discussion and research of problems. Involvement of students to research work is carried out mainly at the main studying level. Results of scientific research make part, and sometimes all contents of course works and theses. For talented students additional classes are given, special programs of training are formed (Bolotova, 2001).

In Norway pedagogical education is focused on development of the general erudition. The Pedagogics is considered as synthesis of science and art that allows students to understand more deeply the spiritual symbols of cultural development forming mentality of the Norwegian society. Pedagogical education in Norway is an important component of educational policy of the state and differs by high degree of flexibility and availability. The main object of the Norwegian pedagogical education is ensuring professional formation and high skill level of the teacher capable to creative comprehension of a pedagogical situation and design of own activity (Hove, 1998).

In the American education system ideas of an activity humanization and the teacher identity prevail. The representative of humanistic Pedagogics A. Kombs orient the teacher on understanding activity as deeply human, motivated by the sincere interest to the personality of the child, respectful relation to him and directed to creation conditions for self-realization of the pupil in school life. The significance of the "humanknowing" knowledge of the teacher which support understanding of people, their mentality and behavior increases. According this a lot of time is allowed to development of communicative abilities of the teacher. In the course of training of future teachers various interactive methods of training are used. The special attention is paid to pedagogical practice, the number of hours for it in training programs increases every year (Goodland, 1990).

The comparative analysis and assessment of pedagogical processes and the phenomena in the developed countries of the world allows to realize a mutual exchange of the best pedagogical practices. The described experience of teachers training in foreign countries can be used to improve the system of elementary school teachers training in Russian high school.

\section{Methodological Framework}

At the present stage of Russian higher pedagogical education development researchers (Pukhovskaya, L. P., M. V.'s Clarain) search for rational approaches in foreign experience of teachers training. At the same time, this experience is almost not presented within future teachers training for elementary school.

Thereby the particular interest within teachers training is S. Dzhensens, K. Pittors, D. Robben's experience (Lyyuvensky Catholic university) who for the purpose of reforming the system of Belgium elementary school teachers training adapted the basic thesis of the "personalized" pedagogical education model of $\mathrm{F}$. Fuller (Pedagogical college of the Texas university) for modern conditions. Within this approach, significant components of successful teachers training are, such as: the differentiated support; support of professional interests; early immersion in teaching; a situation of success already in the first experience of pedagogical 
activity; differentiation of requirements in preparation for lessons; specialized problem orientation in theoretical training; recurrence of a training course (Pukhovskaya, 1997).

Researchers of the psychocognitive theory consider the development of professional (creative and critical) thinking of future teachers by means of the research oriented training as the main goal of professional teacher training process. Here the student joins the situation of independent definition of a problem and its decision; offers approaches; checks possible decisions, proceeding from data; concludes according to the received results; applies conclusions to new data; generalizes (Pukhovskaya, 1997). Future teacher masters not only the procedural party of research activity, but also carries out personal knowledge of daily pedagogical activity, that is form flexible professional thinking. Therefore the student acts as the active creative founder of the own professional training.

Views of one of the representatives of personalitive approach - $\mathrm{L}$. Sprintola are actual. The author considers that levels of personal moral and intellectual development which correlate among themselves, significantly determine progress of pedagogical activity. He gives a huge value to the system of methods of training into which enter: role-playing game "Exchange of positions"; creation of debatable situations about problems of the interpersonal relations; continuous feedback; methods of the direct emotional help to students in imitation of new roles.

One of the most widespread in foreign researches is personally oriented pedagogical education. It considers not only what future teacher acquired, but the main attention orients on why he acquires it? In this regard, the motive predetermines the maintenance of that is acquired and accepted (sense) (Klarin, 1995). Experience of the Belgian scientist G. Kilchterman, in which the personal theory of education is proved, is an example of a combination of personal and activity approaches in the organization of professional teacher training. As the basic component in the process of implementation of the personal theory of education he distinguishes personally developed by the student complex of the dynamic and personally integrated knowledge and belief about school, pupils, teachers, administration, parents, about teaching which is based on an active reflection (Pukhovskaya, 1997). At the present stage of teachers professional education development rather effective is considered a method of reflective training, developed at the State university Ohio, and since 1978 approved in other high schools. This approach induces to reflections about efficiency of the used tutorials and education, promotes expansion of pedagogical experience. Students, exactly realizing difficulties of teaching and educational process and factors which define behavior of the teacher, become interested in own professional development.

In research of the Netherlands scientist J. Byutink the concept of practical knowledge concerning training is proved. "Practical knowledge concerning training" is "all informative abilities and orientations (knowledge, experience, values) of the student that concern his behavior in the process of pedagogical activity". The content of practical pedagogical knowledge consists of: analysis of social behavior of pupils; studying behavior of pupils in the process of training; organization of lessons; own (educational) behavior of the student; teaching a certain discipline. Such researchers as S. Arguris, D. Shyon call practical pedagogical knowledge as "the theory-in-action", that is operative adoption of the practical decision in a concrete pedagogical situation (Pukhovskaya, 1997).

Experience of professional teachers training in Germany is valuable. Researchers F. Budrus, Sh. Regula note that in the process of professional students training it is necessary to form their readiness for professional personal understanding and for harmonious professional integration. It is considered one of the most important factors of professional development formation of communicativeness at the expense of small group in which future teacher isn't afraid to express his views. Involvement of students at seminars into discussions, work on projects, group trainings which have to "expand professional repertoire of behavior", increase "sensitivity of perception" is actively applied (Klarin, 1995).

The concept of the Oxford university "Basic Training of the Teacher as Practical Theorization" is significant today (according to R. Aliksander). Here, theoretical knowledge has to be perceived by students as experimental, called in question, subjected to a possible deviation (Klarin, 1995). Basic preparation is connected with critical studying, improvement and experimental use of ideas which come from different sources, including as knowledge and ability, models of pedagogical work of skilled teachers, as various theoretical and research literature, that is practice theorization.

Thus, generalizing foreign experience in training of teachers it should be noted that it is presented within psychocognitive, personalitive, personal oriented approaches, the concept of practical knowledge concerning training, and also methodical approaches of various educational institutions ("Basic teacher training as practical theorization" the Oxford university, reflexive approach of the State university Ohio). Orientation to practical development of professional abilities is a priority of many foreign psychology and pedagogical and methodical 
researches given above.

\section{Results and Discussion}

\subsection{Forms and Methods of Interactive Students Training}

Transition to new forms of the organization of educational process has to become one of the productive ideas of updating of high school education in Russia, to our mind. Still in high school training lectures prevailed, a practical training was hold with all group, control of independent work on offsets and examinations was aimed at reproduction of knowledge, at state exam as a rule memory and ability to reproduce read (or heard) were checked not the level of formation of professional abilities (competences). It is clear that under such circumstances it is impossible to provide the quality education of the teacher which is necessary for work at modern school.

Developing new approaches to pedagogical manpower training in high school, it is necessary to introduce methods of interactive training which are directed on increase of level of professional competence of the elementary school teacher in educational process. In the process of training of the elementary school teacher it is advisable to use the following methods:

- Carrying out interactive problem lectures, exactly use of the question-answer method throughout all lecture; carrying out the short presentations prepared by students who would disclose one of the questions put in this subject, etc.;

- Introduction during a practical training such forms of work as "a round table", "workshop" where students during discussion solve important problems of specialty on the basis of own independent practices; carrying out debates, discussions, analysis of pedagogical situations, video fragments of lessons;

- Use in teaching and educational process of the higher school of role-playing and business games, a case methods, "brainstorming" which promote development of activity, creativity, the teacher's creativity;

- Holding practical works, master classes, the training lessons promoting formation of professional competence of future elementary school teacher;

- Wide use of electronic educational resources, multimedia means in the course of lecturing and carrying out a practical training, electronic and different types of basic abstracts of lectures, providing educational information to students on electronic media, Internet search and so forth;

- Use of elements of imitation, a reflection, relaxation during a separate practical training;

- Use of new approaches to control and estimation of students achievements which provide their objectivity and reliability.

Methods of active training promote formation of knowledge, professional skills of future experts by attraction them to intensive cognitive activity; activization of thinking of teaching and educational process participants; independent decision-making in the conditions of the increased motivation; interrelations of the teacher and student, etc.

\subsection{Integrity and Multidimensionality of Training Programs}

In the aspect of improvement of professional training of the elementary school teacher the problem of the contents of training programs becomes important. In the last years researches it is told a lot about integrity of training courses, about a multidimensionality of their contents. The other method of strengthening of communications between disciplines which are studied in high school by future elementary school teacher has to become their professional and pedagogical orientation: studying subject disciplines (Russian, Mathematics, Natural Sciences, etc.) the student has to have idea of the maintenance of the corresponding subject studied at the elementary school. In general, the professional and pedagogical orientation has to penetrate all educational process in high school, also to be reflected in the educational and methodical tutorials created for students. Separate conversation is demanded by a psychology and pedagogical and sociological orientation of the maintenance of pedagogical education of future elementary school teachers.

\subsection{Individual Programs of Personal and Professional Development of Students}

One of the most important ways of improvement of professional training of future elementary school teachers is increase the level of theoretical and practical training for innovative activity at school which assumes formation of creative, individual style. In this regard the special place in teaching and educational process of high school is taken by development in students of research and creative abilities. This work allows to create ability to see new in the theory and practice of modern school, to look for non-standard solutions of the problems facing school and 
to bring them to a realization stage at future teachers. The system of the organization of such work demands a phasing (owing to complexity of research abilities), and also shift of accent from formation of research abilities during the writing term and final qualification papers to participation of students in research activity during the studying all disciplines of the curriculum, making research and creative projects. One of conditions for the organization of such work is the problem of studying specific features of future teachers and opportunities of their account in teaching and educational process. Naturally, management of such system demands development of the special program, and also introduction of individual programs of personal and professional development of talented students.

\subsection{Independent Work of Students}

One more problem of high school training of the elementary school teacher is connected with formation of student's ability to study independently. One of this problem means is educational and methodical complexes of disciplines, electronic educational resources where the system of independent work of the student on discipline, including tasks for self-checking, the current and total control has to be presented.

\subsection{Practice-Oriented Training of Students}

The practice — oriented training of students - future elementary school teachers has big reserves. According to it one of the most vexed problems is essentially other organization pedagogical the practices without which it is impossible to carry out modern problems of modernization of education.

It is possible to distinguish the main problems connected with the organization of student teaching in high school: an insufficient number of hours for practice in curricula; a few hours are for teachers to visit the students doing practical training; unwillingness of school teachers to accept on practice of students owing to big additional loading and low payment; low awareness of teachers on specific goals and problems of practice and imperfection of their readiness to work with students in the development plan of professional competences; incoherence of theoretical preparation in higher education institution and school practice.

Overcoming of above-mentioned problems is covered in our opinion in cooperation of the higher pedagogical and elementary comprehensive school. It is obvious that the problem of formation of professional competences of future teacher can't be solved only in pedagogical high school and only by force of high school teachers. The school as the main customer of the new teacher has inevitably to be involved in process of professional training of the student.

\section{Conclusion}

Summing up the results above, it is possible to mark out the following features of professional training of the elementary school teacher in Russian high school at the present stage: use of interactive forms of students education; integrity of the maintenance of training courses, cycles; development of individual programs of personal and professional development of talented students; increase of specific weight of independent work of students; use of the practiceoriented forms of education; reforming of student teaching; accounting of positive experience of professional training of the elementary school teacher in Russia and abroad.

\section{Acknowledgments}

The work is performed according to the Russian Government Program of Competitive Growth of Kazan Federal University

\section{References}

Bogomolova, E. V. (2006). Foreign experience of teachers training (p. 220). Ryazan: Ryazan state university.

Bolotova, A. K., \& Kuzem, O. B. (2001). The organization of the higher pedagogical education in Germany. The Teacher, 5, 46.

Cedelle, L. (2002). Vers de "nouvelles orientations". Le Monde de education, 308, 58.

Clarain, M. V.'s. (1997). Innovations in world Pedagogics: Training on the basis of research, games and discussions. In Analysis of foreign experience (pp. 160-164). Threshing barn: Experiment.

Goodland, J. (1990). Teachers for our nation's schools. In D. Cohen, M. W. McLaughlin, \& J. Talbert (Eds.), Teaching for understanding: Challenges for policy and practice (p. 36). San Francisco: Jossey-Bass.

Greaves, D. H. (1994). The new professionalism: Synthesis of professional and institutional development. Teaching and teacher education: VoblO, 4, 423-438.

Hohlmeier, M. (1999). Für die Zukunft unserer Jugend—Bildungsoffensive Bayern (p. 234). Bayerischer Landtag: 
München:

Hove, O. (1998). The system of Education in Norway (p. 24). O. Hove. Oslo: The Royal Ministry of Church and Education.

Jandhyala, B., \& Tilak, G. (2005). Global trends in the funding of higher education. IAU Horizons (World Higher Education News), 1, 1-3

Mayburov, A. (2003). The higher education in the developed countries. The higher education in Russia, $2,132$.

Nikolaev, M. B. (2011). A problem of professional teacher training in the system of the higher pedagogical education in the conditions of introduction of the Federal state educational standard. News of the Saratov state university, 11, 74-79.

Pukhovskaya, L. P. (1997). Professional training of the teacher in Western Europe (pp. 150-154). Kiev.: The high school.

Voskresenskaya, H. M. (2004). Experience of education standards development in foreign countries. Questions of education, $3,143$.

\section{Copyrights}

Copyright for this article is retained by the author(s), with first publication rights granted to the journal.

This is an open-access article distributed under the terms and conditions of the Creative Commons Attribution license (http://creativecommons.org/licenses/by/3.0/). 